\title{
A PERMANENT BASIS FOR RATE REGULATION,
}

DONALD R RICHBERg

Illinois Bar

Twenty-two years after the decision of Smyth $v$. Ames ${ }^{1}$ we find the elusive principle of rate regulation written down in that celebrated opinion, restated by the Supreme Court of Illinois in the following language:

"The utility is entitled to ask a fair return upon the value of that which it employs for public convenience, but, on the other hand, the public is entitled to demand that no more be exacted from it than the services rendered are reasonably worth."2

In the case just quoted from, the Court made a valiant effort to follow Smyth v. Ames, although it is evident that the insistence of able counsel for the utility upon reproduction cost as the test of value and the insistence of equally able counsel for the public upon original cost, or let us say prudent investment, had demonstrated to the Court that Smyth v. Ames is not a fixed star showing the way to a sound rate basis but merely a will-o-the-wisp leading the explorer into a morass of shifting, uncertain "valuations." The opinion in this Illinois case is particularly worthy of consideration because of the perhaps unconscious candor with which the court demonstrated the unsoundness of the reasoning which it sought to uphold. Following the long line of precedents of the breed of Smyth v. Ames, the Court attempted first to set down the standards for ascertaining the value of a public utility property with the avowed purpose of determining eventually that the public should not pay more for services rendered than they were reasonably worth. But the Court had been uncommonly well educated to an understanding that "value" is a word difficult of definition and that the ascertainment of "value" is a still more difficult matter. The Court had arrived at an intelligence sadly lacking in many other tribunals, and realized that the "value" sought as a rate base could not be an "exchange value" and so the court held:

"Exchange values should not be considered by the Commission in establishing the proper valuation as a basis for rate-making purposes. The exchange value is, in the case of a property whose function is simply to earn money, determined primarily by the earning power and the more unjust and unreasonable the charge made by the utility, the higher the exchange value. ... Exchange value is therefore meas-

1 ( I898) I69 U. S. 466 , I8 Sup. Ct. 418.

'State Utilities Commission v. Springfield Gas Company (I920) 291 Ill. 209, 217, I25 N. E. 89 I, 895 . 
ured by return. The Supreme Court of the United States said in the Minnesota Rate Cases, 'the value of the utility as measured by return cannot be made the criterion when the return itself is in question." "s

Yet, in rejecting exchange value the Illinois Court does not seem to have realized that it has rejected the only pecuniary value which is scientifically ascertainable. Even the Supreme Court of the United States, before it led itself astray with the Smyth v. Ames doctrine, recognized this fact:

"But the value of property results from the use to which it is put and varies with the profitableness of that use, present and prospective, actual and anticipated. There is no pecuniary value outside of that which results from such use."4

Prior to this opinion the Court had held upon similar reasoning that "the value of property, generally speaking, is determined by its productiveness-the profits which its use brings to the owner."

If the Illinois Court had consulted the economists, it would have found them in agreement with the Supreme Court of the United States in limiting any intelligent use of the word "value" in terms of money to: (I) value in exchange; (2) resulting from the profitableness of the use; (3) where the profitableness is determined by competition.

Professor F. W. Taussig states the prevailing view of the economists as follows: ${ }^{6}$

"The value of a commodity means in economics its power of commanding other commodities in exchange. It means the rate at which the commodity exchanges for others. ... The value of a commodity thus conceived is its value in exchange."

John Stuart Mill warned students of economics that values and prices were determined by competition alone and stated a principle which the courts can hardly dispute that "in so far only as they are thus determined can they be reduced to any assignable law."

In a recent article entitled, The "Physical Value" Fallacy in Rate Cases, ${ }^{7}$ Mr. Robert L. Hale has so ably demonstrated that "value" must depend upon earnings and therefore cannot be made the basis for determining the earnings, that any further presentation of this branch of the subject in the present article would be supererogative. The cases which crowd the public utility reports amply prove the accuracy

${ }^{3}$ State Utilities Com. v. Springfield Gas Co., supra, at p. 227, I25 N. E. at p. 899.

${ }^{4}$ C. C. C. \& St. L. Ry. v. Backus (I894) I54 U. S.. 439, 445, I4 Sup. Ct. IIz2, II24.

'Monongahela Nav. Co. v. United States (I893) I48 U. S. 312, 328, I3 Sup. Ct. 622,627 .

- I Principles of Economics (2d ed. IgI5) II5.

' (Ig2I) 30 YaLE Law Journal, 7 Io. 
of Mr. Hale's statement that "this sanctity and certainty of the physical value theory of rates, it is submitted, is the result of loose reasoning and serves merely to divert the time, attention and funds of regulating bodies out of their proper channels into one of the most unreal fields of speculation in which the minds of metaphysicians have disported themselves since the days of the medieval schoolmen." Yet even now, as the courts and commissions show some signs of emerging from the dark ages, there are, as Mr. Hale points out, "authorities who admit that the value depends upon the earnings, but insist that the vicious circle involved (in basing earnings on the value) can be escaped merely by the simple expedient of measuring the value by replacement cost or some other 'evidence.'"

It might have been apparent to the Illinois Court in the light of the considerations above suggested that there could be no pecuniary value fixed for a public utility property (nor for any other property) except on the basis of the profitableness of the use of the property; and that, therefore, no pecuniary value could be fixed until after rates had been fixed; and that then the pecuniary value so fixed would be an exchange value directly reflected in the market price of the stocks and bonds of the utility. The court might have realized that, prior to the determination of the rate, the search for any "value" of the property would be futile and absurd.

It seems clear from other portions of the Illinois opinion that the Court, or certainly the learned Justice who wrote the opinion, understood that the only measurable value of a public utility property is a resultant of the rate, which cannot be ascertained in advance of the rate. One might even suggest that this Court would have stated flatly that a fair rate must be ascertained before the value of the property can be determined had it not been for the brain-paralyzing effect of the statement in Smyth v. Ames that "the basis of all calculations as to the reasonableness of rates. . . . must be the fair value of the property." Even the Supreme Court of the United States has discovered that it can lay down no reliable standards for ascertaining this "value," and has arrived finally at the delphic pronouncements in the Minnesota Rate Cases that "the ascertainment of that value is not controlled by artificial rules. It is not a matter of formulas but there must be a reasonable judgment having its basis in a proper consideration of all relevant facts."8

Public utility commissions, being required to value utility properties upon some basis other than their own unguided opinions, being forced to act usually under pressure from the opposing elements of the public and the public utility operators and then to subject their opinions to judicial review, and, therefore, being desirous of justifying their

(I9r3) 230 U. S. 352, 434, 33 Sup. Ct. 729, 754. 
actions by some fixed rules, have found the "reasonable judgment" approved by the Supreme Court quite useless as a standard for determining a rate base. The result of this condition was well stated in an editorial note in the Michigan Law Review ${ }^{9}$ concluding with the statement:

"The conclusion of this review of recent cases is that the Commissions working at first hand with the practical problems of valuation generally lean more and more decidedly toward fixing value-so-called-of public utilities on prudent investment largely, and in not a few cases, wholly. The courts on the other hand still wallow in the uncertainties of the rule, which is scarcely a rule at all, of Smyth $v$. Ames, making value a question of judgment. In the cases judgments continue to vary as widely as ever."

The opinion of the Illinois Supreme Court in the Springfield Gas Case is particularly interesting as an example of a valiant but vain effort of a court to struggle out of the mire of Smyth v. Ames. Curiously enough this Court set forth a definite, logical, and permanent basis for rate regulation in a few sentences quite at variance with the ultimate efforts of the Court to align its opinion with Smyth $v$. Ames. These sentences excised from the opinion and placed in logical succes-. sion provide a valuable formula for rate regulation.

I. "Fixing rates by public authority may secure to each individual the advantage of collective bargaining by all in behalf of the whole body of consumers and result in such a rate as might properly be supposed to result from free competition, if free competition were possible." (page 2r8)

2. "Ordinarily that is a reasonable charge or system of charges which yields a fair return upon the investment." (page 2I7)

3. "The real test of the justice and reasonableness of any rate seems to be that it should be as low as possible and yet sufficient to induce the investment of capital in the business and its continuance therein." (page 219)

4. "In rate cases the question in determining the value is not how much has been or can be got out of the property, but how much has been put into it, in order that from that fact may be determined how much may be reasonably taken out of it in the way of net income." (page 227)

5. "We consider any value a fair value which fair and reasonable men would say ought to be attached to the property, under all the circumstances of the particular case, for the purpose of measuring a return which the public should pay to the owner." (page 222)

If the above quotations are considered from the standpoint of ascertaining a fair rate (for which definite rules can be laid down) instead of from the standpoint of ascertaining a fair value (for which no

\footnotetext{
' (1921) Ig Mich. L. Rev. 849, 852.
} 
definite rule can be laid down) it will be found that the Court has shown a method of determining what public utility services are reasonably worth without the necessity of first putting an arbitrary and unscientific "value" upon the property.

It is the proposition of the present article that, if the courts and commissions will devote their attention primarily to what public utility services are reasonably worth, they can avoid all the uncertainties and the miseries which have resulted from the Smyth $v$. Ames doctrine. They can put rate making on a reasonably scientific basis and stabilize public utility securities, all of which will benefit both the consumers and the investors. Let us for the remainder of this article forget Smyth $v$. Ames and its horrible brood of supporting opinions and consider again the simple fundamentals of public utility rate regulation, grouping our considerations under the five propositions of the Illinois Supreme Court heretofore set forth.

\section{PROPOSITION NO: I}

The purpose of fixing rates by public authority is to secure for the consumers such a rate "as might properly be supposed to result from free competition if free competition were possible." It seems probable that neither the consumer, the public utility operator, the investor, nor public officials will dispute this proposition. It is appropriate then to consider next what sort of a rate or charge usually results from free competition. Under ordinary competitive conditions the price of any article constantly tends to equal the cost of its production. This cost of production of course includes not merely the cost of materials and labor but also the cost of management and the market cost of capital subjected to similar risks.

"On account of this tendency of prices to equal the expenses of production, the expense of producing a unit of a commodity is called its normal value."10

There are those who have sought to assert that cost of reproduction, rather than cost of production, is the basis for determining normal value. This suggestion is, however, waved aside as insignificant by Alfred Marshall, dean of the English economists, who writes :

"This discussion of the risks of trade has again brought before us the fact that the value of a thing though it tends to equal its normal (money) cost of production, does not coincide with it at any particular time, save by accident. Carey observing this, suggested that we should speak of value in relation to (money) cost of reproduction instead of in relation to cost of production.

"The suggestion has, however, no significance so far as normal values, are concerned. For normal cost of production and normal cost

${ }^{10}$ Ely, Economics (Ig09) bk. 2, part 4, ch. I2, p. I72. 
of reproduction are convertible terms and no real change is made by saying that the normal value of a thing tends to equal its normal (money) cost of reproduction instead of its normal (money) cost of production. The former phrase is less simple than the latter but means the same thing.

"And no valid argument for the change can be founded on the fact, which may be readily admitted, that there are some few cases in which the market value of a thing is nearer its cost of reproduction than the cost that was actually incurred in producing that particular thing. . . . Cost of reproduction exerts little direct influence on value, save when purchasers can conveniently wait for the production of new stipplies."11

Without indulging in an elaborate consideration of this question of economics we may safely assert as a sound, reliable doctrine, which courts and commissions could follow, that the surest method for determining the price of a commodity which would prevail in a condition of free competition is to ascertain what has been and is the cost of producing that commodity. On this basis we may now pass to the second proposition.

\section{PROPOSITION NO. 2}

In the cost of producing a commodity there are to be considered two divisions of expense-the operating cost and the capital cost. If a charge covers all operating costs (including labor, materials, management, maintenance, and all other outgoés necessary to the continuous operation of the business), there is left for consideration only the item of a return upon the money invested. It is obvious that as long as a business produces a fair return on investment and gives reasonable security to investment, money will be available for that business, so that there is no necessity for allowing anything more than a fair return upon investment in order to assure investment. This brings us to the third proposition.

PROPOSITION NO. 3

What is a fair return upon an investment may be measured by the standard set by the Illinois Court that such a return should be "as low as possible and yet sufficient to induce the investment of capital in the business and its continuance therein." It is obvious that the greater the security of capital, the lower will be the interest rate which will induce the investment of capital. A speculative investment requires a higher interest rate, not because the investor expects to earn more, but because he fears he may earn less than through a safer investment. If public utility rates are to be based on fluctuating "valuations" of the property, the investor will demand a higher rate of return than that which would satisfy him from a more stable investment.

${ }^{11}$ I Marshall, Principles of Economics (5th ed. I907) bk. 5, ch. 7, sec. 5, 6. 
Of course rising and falling costs of operation, efficiency and inefficiency of management, and the amount of demand for the service are all factors affecting the security of a public utility investment, but it will hardly be denied that a major factor of uncertainty in investments in regulated public utilities, where accounts are open to the public, where security issues are supervised and the management is exposed to authoritative criticism, is the "valuation" which may be placed on the properties of the utility and thereby determine the earning power of the capital invested.

In the development of the public utilities of the country speculative inducements may have been necessary. In the development of new utilities or utilities in new communities such inducements may still be necessary and a much higher rate of return permitted-with possibly a chance for speculative profit-in order to interest capital. But the principal problems of public utility regulation today involve the regulation of established utilities serving communities assuring a demand for service which can be reasonably estimated. It is submitted that in dealing with this problem a fixed return on investment, subject to no fluctuations on account of revaluations of property, will induce the investment of capital most effectively-particularly because the factors permitting of political attack will be largely eliminated. It is difficult for any politician to combat the request of a public utility for a rate sufficient to pay operating expenses and the prevailing rate of interest on securities representing investment. But where the so-called "value" of the property upon which a return is to be earned in the rates is 100\% greater when that value is estimated by the engineers for the utility than when that value is estimated by engineers representing the public, a fruitful and continuing basis for political controversy is obvious.

An example may be taken from the recent conference report submitted by engineers representing the Company, the City, and the Commission in the appraisal of the properties of The Peoples Gas Light \& Coke Company of Chicago. ${ }^{12}$ The engineers representing these three parties found the historical reproduction cost new of the physical property (without adding overheads, or deducting depreciation, or including working capital, or any going value) to be $\$ 51,307$, II 6 ; the reproduction cost using prices as of a ten-year average (I906-I9I5) \$54,95I, 709 ; the reproduction cost using prices as of July I, I920, $\$ 122,504,470$. Subsequent attempts to state the value of the property, including all factors and based principally on the foregoing figures of structural cost, ranged from the City's low figure of historical cost, including overheads and deducting the accrued depreciation, $\$ 43,401,177$, to the Company's top figure of reproduction cost, $\$ 156,752,68 \mathrm{I}$.

see Order of Public Utilities Commission of Illınois in Proceeding No. 7689, entered December 2I, I920. 
It must be plain that there is no scientific basis for finding a "value" in figures showing such a tremendous variance. It may be mentioned in passing that the Commission fixed the "fair value" at $\$ 85,000,000$, this figure being the result of adding together findings of $\$ 72,000,000$ for "present value" of the property, plus $\$ 7,000,000$ for "going value," plus $\$ 6,000,000$ for working capital. It should be noted again that the figures showing the original cost of the property and reproduction cost on various pricing bases were agreed to by engineers representing the Company, the Commission, and the City, in a conference inaugurated at the suggestion of the writer, who represented the City of Chicago. Therefore in seeking a scientific basis for rate regulation the Commission was not required to reconcile conflicts of testimony between engineers. But the Commission was faced with the impossible task of making a scientific application of the differing cost figures in order to determine that utterly unscientific and indeterminate thing called "the present fair value of the property."

In this case the Commission allowed a rate of $7 \mathrm{I} / 2 \%$ as a fair return upon the "value" of the Company's property. Yet the "values" which the Commission might have found on the testimony presented to it might have varied over $\$ 50,000,000$. Such a variance would have made a difference of $\$ 3,750,000$ a year in gas bills or a difference of more than I2 cents per M. Cu. Ft. in the rate. The Company has appealed from the decision of the Commission.

Gas rates have been a fruitful source of litigation in Chicago for the past fifty years and the main controversy has concerned the "value" of the gas company's property. It must be obvious that by the time the present litigation is settled its determination of the "value" of the Company's property will be practically worthless, if the theory of valuation (to find a rate base) continues effective in the courts. We shall be in a few years in a new era of prices and any conclusions based even in part on present prices must be subject to future revision. In this connection let us note that the stock of this Gas Company, which sold as high as 130 in the year I9I3, sold as low as 28 in the year I9I9, and that its principal bond issue which sold consistently over par up to I9I3 sold as low as 57 in I9I9.

It should be painfully obvious from a consideration of the experience of this utility that if rates are to be based on fluctuating valuations they will not be "as low as possible" and at the same time "sufficient to induce the investment of capital in the business and its continuance therein." But if rates are not to be based upon valuations what should they be based upon? This brings us to the next proposition of the Illinois Supreme Court. 
PROPOSITION NO. 4

After the above exposition of the difficulties to be encountered in establishing the "value" of a public utility property upon the basis of engineers' estimates of the cost of producing or reproducing the property, it is natural to subscribe enthusiastically to the statement of the United States Supreme Court that "never was it held that the cost of a thing is the test of its value."13 Nor is it difficult to approve of the statement of the Illinois Supreme Court in the Springfield Gas Case to the effect that the value of public utility property is not that value sought in consideration of private industrial property and determined by the amount which "can be got out of the property," but is in fact (although the court does not say this) not a "value" at all, but merely a figure which it is reasonable and just to use as a rate base. This must be what the court means when it makes the following pronouncement:

"In rate cases the question in determining the value is not how much has been or can be got out of the property, but how much has been put into it, in order that from that fact may be determined how much may be reasonably taken out of it in the way of net income."14

In this statement the court takes a position, rare among judicial tribunals reviewing rate regulations, in that it plants its feet firmly upon solid ground and states a scientific basis upon which a rate can be determined. The court sets up the standard that a fair return should be based, not upon the theoretical earning capacity of the property, but upon a consideration of what the property represents as investors' sacrifice from which the investor is entitled to a reasonable income.

Would that it were possible to hope that the Supreme Court of the United States may yet emerge from the swamp of Smyth v. Ames and get its feet upon equally solid ground! It seems hopeless to expect that such an emergence may come from any further arguments over how to determine fair value. Twenty years of arguments over methods of determining fair value have finally forced our highest court through statements of rules and qualifications, and restatements and requalifications to the evasive position that ascertainment of value "is not a matter of formulas but there must be a reasonable judgment having its basis in a proper consideration of all relevant facts," leaving what is "reasonable" or "proper" or "relevant" to be determined by each court that passes on the question in each separate case according to its transient opinion. ${ }^{15}$

${ }^{13}$ C. C. C. E St. L. Ry. v. Backus (I894) I54 U. S. 439, 446, I4 Sup. Ct. II22, II24.

${ }^{14}$ Utilities Com. v. Springfield Gas Co. (I920) 29I I1l. 209, 227, I25 N. E. 89I, 899.

${ }^{14}$ Minnesota Rate Cases, supra 8. 
The hope for the introduction of fixed standards for the solution of this very important problem lies rather in presenting rate regulation to the court from a new angle. The eyes of the court have been fixed upon the property rights of the investor, yet the property rights of the investor might be better secured if the court's attention could be drawn to the other factor of equal importance in rate regulation-in fact to the primary purpose of rate regulation-the determination of what the service is reasonably worth.

HOW TO DETERMINE THE WORTH OF THE SERVICE

It is entirely possible to determine what a public utility service is reasonably worth without any effort whatsoever to ascertain the so-called "value" of the public utility property used for furnishing the service. Let us return for the moment to Proposition No. I and endeavor to ascertain "such a rate as might properly be supposed to result from free competition if free competition were possible." In order to make this assumption it is not necessary to assume that there never has been competition and to endeavor to determine the cost of now establishing the competition. During the growth of New York City, for example, there might have been a continual competition in practically all public utility service. As a result, if free competition were possible today, two competing gas plants might be located on real estate which cost each of them $\$ 50,000$. To establish competition today another gas plant might be required to pay $\$ 500,000$ for an equally desirable tract of land. But since the public has always been entitled to a reasonable rate based on the theory of continuing free competition, there is no sound theoretical basis for the assumption of a noncompetitive period and the necessity of suddenly inaugurating competition at the present time in an established community. The ruling of the United States Supreme Court in the Des Moines Gas Case ${ }^{16}$ in refusing to add the cost of cutting through pavements to the reproduction cost of gas mains is in line with this reasoning. There is no reason why the community should pay a tax to public utilities on the wealth created by the community.

From the beginning the privately owned public utility has been furnishing a service which the community itself could have furnished. A consideration of this potential competition shows a sound basis for using the actual cost to the operators of furnishing service as the basis for finding the worth of the service. If a municipality invested $\$ I, 000$, ooo in the real estate necessary for a gas plant and then grew up around the plant to such an extent that the market value of similar real estate adjoining equalled $\$ 2,000,000$, the city officials would never consider

${ }^{10}$ Des Moines Gas Co. v. Des Moines (1915) 238 U. S. 153, 172, 35 Sup. Ct. 8Ir, $8 \mathrm{r} 7$ (commented on Hale, op. cit. 30 Yale Law Journal, 7 Io, 729). 
demanding a return on $\$ 2,000,000$ in the gas rates. It is difficult to see why the service should be reasonably worth any more to the consumer merely because of private ownership of the land upon which the plant is located. In cold fact, the service is not worth any more. Land only increases in value because of its increased earning power, but if the rates of a private gas company are tested from year to year by the standard of assumed competition from a municipally owned plant, the earning power of the gas company's land will not increase.

Applying the legal theory of assumed competition and the concomitant economic theory that under free competition prices tend constantly to equal the cost of service, we can determine the worth of the service furnished by any utility on a mathematical basis by adding to the operating cost the current rate of interest on the capital which actually and prudently has been put into, and remains in, the enterprise. If the books of a utility are properly kept, those books will show the exact amount of money which has been invested. If the books are not properly kept competent engineers and accountants can determine with seasonable accuracy the amount of prudent investment which must have been made in the development of the properties, using the historical reproduction cost, not as the basis for determining any elusive "value" of the property, but for the simple purpose of determining the capital cost of the service.

The rate of return will vary from time to time as the market rate for money changes. Here again it should not be the theoretical cost of theoretical capital but the actual cost of actual capital which should be considered in the rate of return. If the company has a long term issue of bonds bearing $5 \%$ interest, the company should be allowed the cost actually incurred to obtain and use this capital. If the companiy has stock outstanding, the money represented by that stock should carry the current rate of interest for securities of similar standing. This will enable the company to issue at par further stock as funds are required. for extensions.

It may be objected to this theory of rate regulation that while it could be applied fairly and scientifically to a newly organized utility, nevertheless, where utilities have been developed through the unregulated period, through the period when public utility development was a speculative business and when large amounts of securities representing no investment were issued in order to induce the investment of the necessary amount of actual capital, this will be a policy destructive of large present values in public utility securities, destructive of credit necessary for the present efficient operation of such utilities, and a cause of grave hardship to thousands of investors and of general injury to public utility service.

It must be admitted that any policy of public utility regulation today which lifts an unfair burden from many consumers will place that bur- 
den upon the investors. It is also often difficult to determine whether the consuming public or the investing public should in all fairness carry this burden. It is easy for a representative of the public to assert that the investor, who has bought securities not representing actual capital investment, should suffer the loss caused by his own bad judgment. It is easy for an investor to assert that the public, which permitted and even encouraged the exploitation of public service, should bear the burden of that exploitation. It is often difficult to draw a legal line sharply between what has been an honest speculation in public utilities and a dishonest exploitation. But if each public utility is considered separately it should be possible to draw an equitable line. It should be possible to weigh the relative cost to the public of a period of disorganization of a public service through the requirement of a complete financial reorganization of a public service company and a continued carrying of an excessive burden by the public in order to maintain the continuity of efficient public service.

For example, a certain gas company has been required to amortize, at the rate of $\$ 200,000$ a year, a payment of some $\$ 5,000,000$ representing no addition to its property. This means an addition to the gas rate of about two-thirds of a cent per $\mathrm{M}$. Cu. Ft. if this amortization charge is added to operating expenses, or the sacrifice of about $1 / 2 \%$ in dividends if it is taken out of the stockholders. But if this $\$ 5,000,000$ were made the basis for an addition to capital, upon which a rate of return of $7 \mathrm{~T} / 2 \%$ were allowed, this would mean a continuing charge of $\$ 375,000$ a year or about .oI $1 / 4$ per M. Cu. Ft. of gas. Certainly it is better to begin a new policy, whether the burden of it shall be imposed upon the consumer or the investor or divided between them. In a few years both the consumer and the investor will begin to profit by the establishment of any sound and permanent basis for rate regulation.

PROPOSITION NO. 5

There are considerations such as those last referred to, which should be taken into account by commissions and courts in fixing the rate basis as the amount "which fair and reasonable men would say ought to be attached to the property under all the circumstances of the particular case for the purpose of measuring a return which the public should pay to the owner." In dealing with the difficulties which have arisen out of the development of public utilities through a long unregulated period we enter upon a field for the application of equitable principles. In this field there is a splendid opportunity for intelligent and courageous negotiation between representatives of the public and representatives of the utilities to establish a permanent rate base to represent what may be called the investment in each public utility at the time of the establishment of the permanent base. All future additions to such a rate base should represent actual additions to the capital investment. 
The factors to be considered in such negotiations are well described in an article by Mr. Gerard C. Henderson, entitled, Railway Valuation and the Courts. ${ }^{17}$ But if out of such negotiations could come an end to political controversies over utility rates, an end to wide fluctuations in market values of public utility securities, an end to exorbitant interest rates for financing necessary developments of public service, even the cost of several million dollars of unjust charges for capital, imposed upon the public, would be reimbursed in the next generation many times over through the improvement of the public service and the resulting improved prosperity of the country.

There might be a distinction made, in endeavoring to ascertain that amount which fair and reasonable men would say should be used "for the purpose of measuring a return which the public should pay," between the validation of securities representing no money investment which were issued as a part of the original construction of the utility, and those which may have been issued in some later financial exploitation.

For example, in constructing a line of elevated railroad in the City of Chicago at an actual cost of about $\$ 2,500,000$, five million dollars of bonds and five million dollars of stock were issued. The construction company which took $\$ 5,000,000$ of bonds in a speculative enterprise in payment for its actual cash outlays accepted a certain risk, and to validate the excess $\$ 2,500,000$ of bonds means principally that the public pays Io\% interest for a public utility service because capital could not be induced to supply the service at a lower rate. It might be argued that even the promoters who took the $\$ 5,000,000$ of stock were entitled to levy a considerable tax upon the public service because of the risks they took and the energy and foresight which they exercised in providing that service.

As another type of exploitation may be cited the financial reorganization of the Chicago \& Alton under the late E. H. Harriman whereby, according to the report of the Interstate Commerce Commission, some $\$ 60,000,000$ of securities were imposed as a burden on public service without the addition of a dollar of actual capital. Representatives of the public might well hesitate to write this $\$ 60,000,000$ into a permanent rate base.

As indicated by the foregoing examples there are two separate lines of policy which must be utilized by representatives of the public and by public utility operators in endeavoring to work out a permanent solution for the problem of the regulation of public utilities. This generation inherits a mass of difficult questions which must be solved individually for each utility in the endeavor to do justice to consumer and investor, and in the solution of these questions there is room for

\footnotetext{
17 (I920) 33 HaRv. L, REv. 902.
} 
and neccesity for a "reasonable judgment," a weighing of equitable considerations, a striking of a balance between expediencies.

This generation also faces the necessity of establishing a line of future policy whereby the basis of future regulation of public utilities can be made certain and permanent. It is hopeless to seek for a future policy to prevail under public regulation which can be applied absolutely to the solving of utility problems which have arisen during the unregulated period. Each problem arising out of a period of non-regulation must be treated separately. But the problems of the future, if they are to be handled intelligently, should find their solution in the establishment of a.definite scientific method for determining a rate base. There is nothing definite or scientific in a shifting rate base determined by the revaluation of public utility properties every few years as price levels shift or as general community values rise and decline.

Since this article has been written largely from the standpoint of the consumer, let us consider for a moment the standpoint of the investor. There is a great need today for stocks and bonds of assured earning power offering an exceptionally sound security, for the investment of trust funds or for provision by people of small means against accident, disability, and old age. There is a great demand for such securities for the investment of funds of banks and insurance companies and for the surpluses of large corporations. Public utility securities should offer an ideal investment for such funds and public utility securities should always command the necessary capital for the extension and improvement of public utility service, upon which the prosperity of the commercial life and the comfort of the social life of every community in a large part depends.

Through a long era of rapid commercial growth under a philosophy of rampant individualism and unrestricted freedom of private enterprise, the public utilities of the country have been developed as private speculations. We have now come to realize the menace to the national welfare of unregulated private control of necessities. We have been experimenting for about fifty years with public regulation. If public regulation fails we shall undoubtedly embark on extensive experiments in public ownership. Those who believe most sincerely in private ownership should lend their best efforts to insure the success of public regulation. But if public regulation is to succeed, it must be based upon fixed standards and principles so that our regulatory bodies may function as exponents of a "government of laws, not of men."

Professor F. W. Taussig has well written:

"It is not too much to say that the future of democracy will depend on its success in dealing with the problems of public ownership and regulation."18

\footnotetext{
${ }_{2}^{18}$ Principles of Economics (IgIr) $4 \mathrm{II}$.
} 
In dealing with the problem of rate regulation it has become quite clear that to state that "rates should be based upon the fair value of the property utilized in public service" is not to state a principle but merely to evade such a statement. When the earning power of a property is the very question at issue and when any ascertainable "value" is the result and not the cause of the earning power, it is a scientific impossibility to find the value of a property before determining its earning power.

If, however, the principle is established that the earning power of a public utility property should be allowed to equal, but not to exceed, the cost of the service, then a rate may be determined by the mathematical calculation of that rate which will return to the operators the cost of operation and the cost to the operators of the capital which they have actually and necessarily employed in the enterprise. If part of that capital has been contributed by the public, there will remain the question as to whether the public contributed the capital to the private owners to induce them to establish the enterprise (as in the case of land donations) or as to whether the public has merely contributed the use of the capital, in which latter case the private owners of the remainder of the property have no basis for charging the public for the use which they obtain without cost.

The main necessity for clear thinking in the field of public utility regulation seems to the present writer to be to substitute the use of the understandable word "cost" for the use of the unintelligible word "value."

To those opportunists who will seize immediately upon the word "cost" and demand that cost to reproduce should be made the standard, two answers may be suggested.

First, the only possible argument in favor of cost of reproduction springs from the analogous use of cost of reproduction in private competitive business. That is, it is fallaciously claimed that since cost of reproduction may determine the competitive cost in private business, therefore it should determine the potential competitive cost in public utility service. But the cost of reproduction so far as utilized in establishing prices in private business is not the cost of reproducing the identical property but the cost of reproducing an equally serviceable property. Or, let us say, it is the cost of reproducing the article or service, or an equally useful article or service, and never the cost of reproducing a particular plant. In truth, invention and improvement work changes in all industrial operations so rapidly that it is difficult to find any plant a few years old which would be reproduced by competent engineers in the same form today. Therefore, to utilize the idea of cost of reproduction intelligently is not to utilize the cost of reproduction of any particular property but of a service or of an equally useful service. It must be apparent that such a basis for rate making would 
open up a new field for speculative estimating, to the increased profit of engineers and lawyers and to the increased confusion of the courts and commissions and would bring increasing instability to all public utility operations.

Second, it should be pointed out that we are at present quite obviously entering upon a period of declining prices and that in determining a rate base any use of figures representing the cost to reproduce the identical property will deprive public utilities in the near future of any return upon millions of dollars of actual investments which have been made in the last few years in properties which may be reproduced in the years soon to come for less than the amount of the investments which they represent. In such a time it will seem as unfair to the investor that his investment should be scaled down and that the return on his capital should be diminished because of declining price levels as it has seemed unfair to the consumer that the investor's capital should be inflated and his return increased because of rising. price levels.

The essential theory which seems more just is that investment in public utility securities, whether denominated as stock or bonds, should be regarded practically as an investment in bonds bearing a fixed return with the principal protected against impairment through appropriate depreciation and maintenance charges. It would seem a sound principle to regard the operators of public utilities as trustees of the service for the public and of the capital invested for the security holders. It should be their obligation to keep costs as low as consistent with efficient service and to do all in their power to insure investors of capital a safe non-speculative rate of return. Public utility operators who recognize these obligations cannot support theories of public utility regulation which make public utility securities a speculative investment and subject public utility service to the hazards of speculative enterprise.

Public utility operators and public officials alike, who are not financial or political demagogues, should join in a demand for the establishment in the courts and commissions of the doctrine that a reasonable rate for public utility service should be fixed on the basis of the reasonable cost of the service and that the reasonable cost of the service should be ascertained by the addition to current operating expenses of the amount of interest required to recompense at market rates the capital actually and prudently employed in producing the service and to induce the further investment of capital needed for desirable extensions and improvements.

\section{A CONSTITUTIONAL QUESTION}

Before closing this article perhaps brief consideration should be given to the question inevitably presented to a proponent of the theory 
of prudent investment. Would a rate basis so established, either by commissions or by act of the legislature, be held constitutional in the courts of last resort? It is common to approach this question from the $a$ priori assumption that we are endeavoring to find the value of the public utility property. On this assumption the courts have reasoned that the value of the property is not determined by original cost figures or by investment figures but is something changing from day to day according to surrounding conditions and that, at any particular time, unless the owners of public utility property are permitted to earn a fair return upon the "present value" of the property, they will be deprived of a part of the value of their property, and thereby deprived of property. ${ }^{19}$

The reasoning that follows on this assumption loses its force if the fact is accepted that not only is it unnecessary to determine the value of the property prior to fixing the rates but that as a matter of fact no value for the property can be determined prior to fixing the rates except that value which the property has by virtue of its existing earning power. Of course it is obvious that the existing actual value is not to be protected by the courts because on such a theory rates would have to be maintained always on the basis necessary to maintain the earning power of the property exactly as when regulation of the utility first began. If the courts can be brought to realize that the word "value" means nothing except a resultant of earning power and that the value of a property cannot be ascertained until after its earning power is fixed, then figures showing the prudent investment in a property can be presented, not as evidence of the value of the property, but as evidence of the cost to the owners of the property of providing public service. The courts viewing the operators of the property as trustees who must obtain from the public reimbursement for outgoes, will find the evidence of the prudent investment in the property relevant and essential to determine the amount of capital upon which the operators must pay the market rate in order to continue to furnish service. In this investigation there is no inquiry whatsoever as to the value of the property. In fact, the question of the value of the property is entirely irrelevant.

For example, a public utility plant is located on real estate which cost $\$ 100,000$ twenty years ago. Adjoining real estate of equal size now is worth $\$ 500,000$. Of course if the rates are to be based on the "value" of the company's property then each particular piece of property must be given a "value." As evidence of this value the court may receive testimony concerning the amount actually paid for the property and estimates of experts as to what the property could be sold for today

${ }^{19}$ There is an admirable discussion of this judicial theory in Mr. Hale's article from which quotation has been made heretofore. See Hale, op. cit. 30 YALE LAW JoURNAL, 7IO. 
and other evidence customarily utilized in valuing property held in private ownership. But if the court is endeavoring to find out the cost of public utility service so that the operators, who are quasi-public servants, may be reimbursed in the rates for the cost of furnishing the service, the court will not be interested in seeking to find the value of any specific items of the company's property. The court will find it necessary only to ascertain, in the language of the Supreme Court of Illinois," "how much has been put into it (the property) in order that from that fact may be determined how much may be reasonably taken out of it in the way of net income."

It will be observed, therefore, that in fixing rates on the basis of cost of service, all constitutional questions as to depriving an owner of his property, or of a part of the so-called value of his property, are avoided because the court does not make any effort to ascertain the value of the property and the court by its ruling does not take from the owner any value which may be claimed on any theory. The court merely applies to the facts presented the legal principle that the consumer is entitled to obtain public utility service for what it is reasonably worth; that it is reasonably worth what it would cost under conditions of free competition; that under the conditions of free competition the cost of the service to the consumer constantly approaches the cost of producing the service; and that, therefore, when the actual cost of producing the service is ascertained, the worth of the service to the consumer, that is, a just and reasonable rate, is ascertained; and at no stage in this process has the court concerned itself with any hypothetical "value" of the property of the owners of the utility or in fact found it necessary to consider in any way rights of property of public utility owners.

It is apparent that such a method of rate regulation may deprive owners of utilities of profits which they might make under a different system of regulation, but that consideration is quite irrelevant. Exercises of legislative power, particularly in the domain of the police power, constantly and almost invariably operate to deprive individuals of profits which they might earn in the absence of such exercise of power. But if the authority of the State to enforce a regulatory principle is once admitted, the incidental effect of such enforcement upon the profitableness of business operations (and if you please, on the resultant "values" of properties utilized in business) is immaterial and irrelevant. If, therefore, the State has authority to require that public service be rendered to the consumer at its reasonable worth and the corollary to that principle is established that reasonable worth is ascertained by assuming a condition of free competition, then the question of the effect on private profits of the imposition of that requirement upon public utilities becomes wholly irrelevant.

${ }^{20}$ Utilities Commission v. Springfield Gas Company (1920) 29r I11. 209, 227, I25 N. E. 89I, 899 . 
There is one further suggestion which may make clear why there is no necessity for meeting the question of unconstitutional deprivation of property in the case of rate regulation. The word "property" is as commonly misused as the word "value." "Property" in its exact sense means the rights of the owner in the thing possessed. It means the domain which the owner is permitted by law to exercise over the thing possessed.

"In its proper use the term 'property' applies only to the rights of the owner in the thing possessed.",21

"Property, in its broader sense, is not the physical thing which may be the subject of ownership, but is the right of dominion, possession and power of disposition which may be acquired over it; and the right of property, preserved by the constitution, is the right not only to possess and enjoy it, but also to acquire it in any lawful mode, or by any lawful industrial pursuit which the citizen, in the exercise of the liberty guaranteed, may choose to adopt." 22

In a recent case in the United States Supreme Court the true definition of property was utilized. Mr. Justice Holmes wrote ${ }^{23}$

"Property, a creation of the law, does not arise from value, although exchangeable as a matter of law. Many exchangeable values may be destroyed intentionally without compensation. Property depends upon exclusion by law from interference, ....."

Mr. Justice Brandeis, dissenting, wrote :24

"The essential element of individual property is the legal right to exclude others from enjoying it. If the property is private, the right of exclusion may be absolute. If the property is affected with the public interest, the right of exclusion is qualified.".

It is axiomatic that owners of land or other physical things, devoting such things to public service by that very act limit their property interests. If the profitableness of the use of investment in public utility service is diminished by state enforcement of principles which are accepted as a limitation on private operation of public utilities, the property owner cannot possibly complain that he is deprived of property by action of the state, because he himself by devoting his money or some other valuable thing to public utility service has accepted a limitation upon his dominion in the things he possesses, so that he has no property rights which are taken away by enforcement of the accepted principles of public utility operation. Even Mr. Justice Brewer pointed this out, although in dictum:

\footnotetext{
${ }^{21} 23$ A. \& E. Enc. Law, 26I.

"Braceville Coal Co. v. People (I893) I47 IIl. 66, 7I, 35 N. E. 62, 63.

${ }^{23}$ International News Service v. Associated Press (I9I8) 248 U. S. 215, 246, 39 Sup. Ct. 68, 75 .

${ }^{21}$ Ibid. at p. 250, 39 Sup. Ct. at p. 76.
} 
"If in such case an individual is willing to undertake the work of the State, may it not be urged that he in a measure subjects himself to the same rules of action, and that if the body which expresses the judgment of the State believes that the particular service should be rendered without profit he is not at liberty to complain? ... . Is there not force in the suggestion that as the State may do the work without a profit, if he voluntarily undertakes to act for the State he must submit to a like determination as to the paramount interests of the public?"25

The Supreme Court of Illinois in a case affirmed by the Supreme Court of the United States said:

"Where lands are restricted, by law or by the terms of a grant, to a particular use, the measure of compensation, in a condemnation proceeding, to the owner for the lands taken will be their value to him for the special use to which they are restricted. . . Hence, we think that there was no error in excluding testimony offered for the purpose of showing the general salable value of the right of way included in the crossing, or its general value for other uses than that to which it was applied." ${ }^{26}$

It is submitted that public utility rates should be fixed upon standards which would eliminate automatically from the cases any constitutional question as to deprivation of property. The property of the owners of public utilities is the dominion which under the law they are permitted to exercise over the things possessed. That dominion is subject to a paramount obligation to furnish service to the public at what the service is reasonably worth. The service is reasonably worth to the public what it costs to produce it. The cost of production is the cost of operation and the cost of obtaining and retaining the necessary capital to establish and operate the machinery that furnishes public service. The only ascertainable value of a public utility property is the capitalization of the earning power of that property, under rates determined on the basis of finding what amount is necessary to reimburse the company for the cost of furnishing the maximum amount of service which the community will absorb. If rates for a utility are once fixed upon this basis, it will be found that a permanent rate base has been determined and that the increase or decrease of the amount of that rate base in the future will be principally a process of mathematical computation, forming no proper basis either for political controversy or for the expensive and wasteful proceedings known as valuation hearings. The establishment of such a permanent basis for rate regulation will go far toward bringing about a new stability in public utility securities, and a greatly increased and healthy prosperity for the utilities and for the communities, whose business growth and social comfort depend so largely upon public utility service.

${ }^{25}$ Cotting v. Kansas City Stock Yards Co. (Igor) 183 U. S. 79, 93, 22 Sup. Ct. $30,36$.

${ }^{26}$ C. B. \& Q. Ry. v. City of Chicago (I894) I49 I11. 457,46 r, 37 N. E. 78, 79; see also Chicago, etc. Ry. v. Catholic Bishop (I887) IIg I11. 525, ro N. E. 372. 